\title{
The Possible Role of Hydrogen Sulfide as an Endogenous Neuromodulator
}

\author{
Kazuho Abe and Hideo Kimura \\ The Salk Institute for Biological Studies, San Diego, California 92138
}

Hydrogen sulfide $\left(\mathrm{H}_{2} \mathrm{~S}\right)$, which is well known as a toxic gas, is produced endogenously from L-cysteine in mammalian tissues. $\mathrm{H}_{2} \mathrm{~S}$ is present at relatively high levels in the brain, suggesting that it has a physiological function. Two other gases, nitric oxide and carbon monoxide, are also endogenously produced and have been proposed as neuronal messengers in the brain. In this work we show the following: (1) an $\mathrm{H}_{2} \mathrm{~S}$-producing enzyme, cystathionine $\beta$-synthase (CBS), is highly expressed in the hippocampus; (2) CBS inhibitors hydroxylamine and aminooxyacetate suppress the production of brain $\mathrm{H}_{2} \mathrm{~S}$; and (3) a
CBS activator, S-adenosyl-L-methionine, enhances $\mathrm{H}_{2} \mathrm{~S}$ production, indicating that CBS contributes to the production of endogenous $\mathrm{H}_{2} \mathrm{~S}$. We also show that physiological concentrations of $\mathrm{H}_{2} \mathrm{~S}$ selectively enhance NMDA receptor-mediated responses and facilitate the induction of hippocampal longterm potentiation. These observations suggest that endogenous $\mathrm{H}_{2} \mathrm{~S}$ functions as a neuromodulator in the brain.

Key words: hydrogen sulfide; cystathionine $\beta$-synthase; longterm potentiation; NMDA receptors; hippocampus
Endogenous hydrogen sulfide $\left(\mathrm{H}_{2} \mathrm{~S}\right)$ can be formed from cysteine by pyriduxal-5'-phosphate-dependent enzynes, including cystathionine $\beta$-synthase (CBS) and cystathionine $\gamma$-lyase (CSE) (Stipanuk and Beck, 1982; Griffith, 1987; Erickson et al., 1990; Swaroop et al., 1992). Both CBS and CSE have been intensively studied for their activities in the liver and kidney (Stipanuk and Beck, 1982; Erickson et al., 1990; Swaroop et al., 1992), but little is known about them in the brain. Recently, endogenous levels of $\mathrm{H}_{2} \mathrm{~S}$ in the brain have been measured in the rat, human, and bovine (Goodwin et al., 1989; Warenycia et al., 1989a; Savage and Gould, 1990). The relatively high concentration of endogenous $\mathrm{H}_{2} \mathrm{~S}$ in the brain $(50-160 \mu \mathrm{M})$ suggests that it has a physiological function.

Although it has not been possible to determine which form of $\mathrm{H}_{2} \mathrm{~S}\left(\mathrm{H}_{2} \mathrm{~S}, \mathrm{HS}^{-}\right.$, or $\left.\mathrm{S}^{2-}\right)$ is active, the term "hydrogen sulfide" has been used in toxicity studies. The term "hydrogen sulfide" is also used here. Most studies about $\mathrm{H}_{2} \mathrm{~S}$ have been devoted to its toxic effects (Reiffenstein et al., 1992) with little attention paid to its physiological function. Two other gases, nitric oxide (NO) and carbon monoxide (CO), are also produced endogenously by enzymes localized in the brain. NO is produced by NO synthase via the metabolism of arginine (Palmer et al., 1988; Bredt and Snyder, 1992), and $\mathrm{CO}$ is produced by heme oxygenase via the metabolism of heme to biliverdin (Maines, 1988). Both NO and CO have been proposed as retrograde messengers in hippocampal long-term potentiation (LTP) (O'Dell et al., 1991; Schuman and Madison, 1991; Haley et al., 1992; Stevens and Wang, 1993; Zhuo et al., 1993), a synaptic model of learning and memory (Bliss and Collingridge, 1993).

The $\mathrm{H}_{2} \mathrm{~S}$-producing enzyme CBS was found to be highly expressed

Received Aug. 8, 1995; revised Nov. 29, 1995; accepted Dec. 4, 1995

This work was supported by grants from the National Institutes of Health (NIH) to Dr. David Schubert (R01NS09658) and from the NIH (R29NS31202) and the Alzheimer's Association to H.K. K.A. was supported by NIH Grant R01NS09658. We thank Dr. J. P. Kraus for a CBS cDNA plasmid and Dr. P. F. Erickson for a CSE cDNA plasmid. We thank Drs. D. Schubert, J. P. Kraus, and P. F. Erickson for discussions. We also thank Drs. D. Schubert, T. Saitoh, Y. Goda, Y. Sagara, and P. Maher for reading this manuscript.

Correspondence should be addressed to Hideo Kimura, The Salk Institute for Biological Studies, P.O. Box 85800, San Dicgo, CA 92138.

Copyright 1996 Socicty for Neuroscience $0270-6474 / 96 / 161066-06 \$ 05.00 / 0$ in the hippocampus and cerebellum in the present study. Brain homogenates produce $\mathrm{H}_{2} \mathrm{~S}$ in the presence of cysteine and pyridoxal5 -phosphate. The production of $\mathrm{H}_{2} \mathrm{~S}$ is inhibited by CBS inhibitors hydroxylamine and amino-oxyacetate and is increased by an activator of CBS, $S$-adenosyl-L-methionine (AdoMet), indicating that CBS contributes to the production of endogenous $\mathrm{H}_{2} \mathrm{~S}$. Although high concentrations of $\mathrm{H}_{2} \mathrm{~S}$ inhibit synaptic responses, physiological concentrations of $\mathrm{H}_{2} \mathrm{~S}$ facilitate the induction of LTP in the hippocampus. These observations suggest that endogenous $\mathrm{H}_{2} \mathrm{~S}$ functions as a neuromodulator in the brain.

\section{MATERIALS AND METHODS}

Northem blot analysis. Total RNAs $(10 \mu \mathrm{g})$ were electrophoresed in a 0.66 $M$ formaldehyde denaturing gel and blotted on Hybond-N nylon membrane (Amersham, Arlington Heights, IL). Hybridization was performed in a solution of $50 \%$ formamide, $0.65 \mathrm{M} \mathrm{NaCl}, 0.2 \%$ SDS, and $100 \mu \mathrm{g} / \mathrm{ml}$ salmon sperm DNA at $42^{\circ} \mathrm{C}$ for $16 \mathrm{hr}$, and the blot was then washed twice with $0.1 \times \mathrm{SSC}, 0.2 \%$ SDS for $30 \mathrm{~min}$ at $65^{\circ} \mathrm{C}$.

Measurement of $\mathrm{H}_{2} \mathrm{~S}$ production. Enzymatic capacity for $\mathrm{H}_{2} \mathrm{~S}$ production in brain homogenates was measured according to the method by Stipanuk and Beck (1982). Briefly, the whole brain was isolated from adult rats and homogenized in ice-cold $50 \mathrm{~mm}$ potassium phosphate buffer, pH 6.8, with a Polytron homogenizer (KINEMATICA, Lucerne, Switzerland). One milliliter of an assay reaction mixture contained (in $\mathrm{mM}$ ): 10 L-cysteine, 2 pyridoxal 5'-phosphate, 100 potassium phosphate buffer, $\mathrm{pH} 7.4$, and $12 \%(\mathrm{w} / \mathrm{v})$ brain homogenate. D,L-Propargylglycine $(2$ $\mathrm{mM})$ and $S$-adenosyl-L-methionine $(2 \mathrm{~mm})$ were incubated with tissue homogenates before the enzyme reaction at $37^{\circ} \mathrm{C}$ for 5 and $15 \mathrm{~min}$. respectively. All the other inhibitors were added to a final reaction mixture at concentrations shown in Figure 2, and the enzyme activities were measured. Incubations for the enzyme reactions were performed in $25 \mathrm{ml}$ Erlenmeyer flasks fitted with septum stoppers and plastic center wells (Kontes, Vineland, NJ). Center wells were filled with $0.5 \mathrm{ml}$ of $1 \%$ $(\mathrm{w} / \mathrm{v})$ zinc acetate and a filter paper for trapping evolved $\mathrm{H}_{2} \mathrm{~S}$ as zinc sulfide. Each flask was flushed with $\mathrm{N}_{2}$ for $20 \mathrm{sec}$ and then sealed. The reactions were initiated by transferring the flasks from an ice bath to a $37^{\circ} \mathrm{C}$ shaking water bath. After $90 \mathrm{~min}$ at $37^{\circ} \mathrm{C}$, reactions were stopped by injecting $0.5 \mathrm{ml}$ of $50 \%(\mathrm{w} / \mathrm{v})$ trichloroacetic acid. Flasks were incubated in the shaking water bath at $37^{\circ} \mathrm{C}$ for an additional hour to complete trapping of $\mathrm{H}_{2} \mathrm{~S}$. The center wells and contents were transferred to test tubes and mixed with $3.5 \mathrm{ml}$ of distilled water. To each tube, $0.4 \mathrm{ml}$ of 20 mM $N, N$-dimethyl-p-phenylenediamine sulfate in $7.2 \mathrm{M} \mathrm{HCl}$ was added, immediately followed by the addition of $0.4 \mathrm{ml}$ of $30 \mathrm{mM} \mathrm{FeCl}_{3}$ in $1.2 \mathrm{M}$ $\mathrm{HCl}$. After $20 \mathrm{~min}$ of incubation at room temperature, the absorbance of the resulting solution at $670 \mathrm{~nm}$ was measured with a spectrophotometer. All assays were done in duplicate. The calibration curve of absorbance versus sulfide concentration was made by using defined concentrations of 
sodium hydrosulfide (NaHS) solution. A stock solution of NaHS (100 $\mathrm{mM}$ ) was prepared by dissolving $\mathrm{NaHS}$ compensated with the ratio of $\mathrm{NaHS} / \mathrm{H}_{2} \mathrm{O}$ immediately before use.

Electrophysiology. Hippocampal slices $(400-450 \mu \mathrm{m})$ were prepared from Sprague-Dawley rats (3-6 weeks old for LTP experiments and $12-15 \mathrm{~d}$ old for whole-cell recordings) and maintained in a chamber (1.5 $\mathrm{ml})$ at $34^{\circ} \mathrm{C}$, where they were continuously perfused with artificial CSF (ACSF) consisting of (in mM): $124 \mathrm{NaCl}, 4 \mathrm{KCl}, 2.4 \mathrm{CaCl}_{2}, 1.3 \mathrm{MgSO}_{4}$, $1.24 \mathrm{NaH}_{2} \mathrm{PO}_{4}, 26 \mathrm{NaHCO}_{3}$, and 10 glucose, bubbled with $95 \% \mathrm{O}_{2}$ / $5 \% \mathrm{CO}_{2}$.

A bipolar stimulating electrode was placed in the stratum radiatum in the CA1/CA2 border region, and the evoked EPSP and the population spike were extracellularly recorded from the stratum radiatum and the pyramidal cell layer in the CA1 region, respectively, with a glass capillary microelectrode $(3-5 \mathrm{M} \Omega$ ) filled with $0.9 \% \mathrm{NaCl}$. A single test stimulation ( 0.1 msec duration) was applied at intervals of $20 \mathrm{sec}$. The stimulus intensity was adjusted in the range of $35-55 \mu \mathrm{A}$ to evoke $0.8-1.0 \mathrm{mV}$ of the field EPSPs, and in the range of $50-100 \mu \mathrm{A}$ which induce $50 \%$ of the maximum amplitude for the population spikes. Changes in field potential were recorded in current clamp mode with an Axopatch $200 \mathrm{~A}$ amplifier (Axon Instruments, Foster City, CA) and digitized with a DigiData 1200 analog-to-digital converter (Axon Instruments). Nine consecutive records were averaged, and the data were stored on a computer (Datel 486, San Diego, CA).

To induce potentiation of evoked field potentials, a tetanic stimulation was applied at the same intensity with the test stimulation for the population spikes and at twice as much intensity for field EPSPs. Nine consecutive records were averaged and the data were collected at intervals of $3 \mathrm{~min}$. After all LTP experiments, a strong tetanic stimulation (100 pulses at $100 \mathrm{~Hz}$, twice at an interval of $20 \mathrm{sec}$ ) was applied to determine whether slices were able to induce LTP.

To record membrane currents induced by NMDA or AMPA, wholecell patch recording was performed in CA1 pyramidal neurons in hippocampal slices. Patch electrodes $(4-4.5 \mathrm{M} \Omega)$ were filled with an internal solution consisting of (in $\mathrm{mM}$ ): $113 \mathrm{CsF}, 7 \mathrm{KCl}, 1 \mathrm{MgCl}_{2}, 1 \mathrm{CaCl}_{2}, 10$ EGTA, $2 \mathrm{Mg}$-ATP, and $10 \mathrm{HEPES}, \mathrm{pH}$ 7.3. After a cell-attached gigaohm seal was made, the whole-cell recording was achieved by applying additional suction to rupture the membrane patch. Membrane potential was clamped at $-60 \mathrm{mV}$, and membrane currents were monitored using an Axopatch 200A amplifier. The cells were allowed to equilibrate for $10-15$ min until the baseline membrane current became stable. NMDA ( $20 \mu \mathrm{M})$ or AMPA $(10 \mu \mathrm{M})$ was added to ACSF and applied by perfusion (1.5

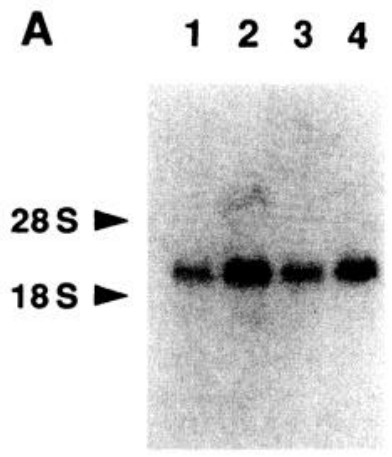

B

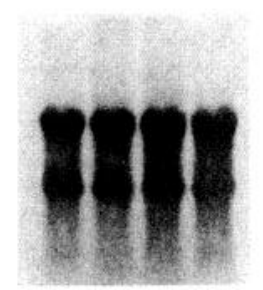

Figure 1. Expression of CBS mRNA in the brain. $A$, Northern blot analysis of total RNA extracted from the cerebral cortex (lane 1), hippocampus (lane 2), brainstem (lane 3), and cerebellum (lane 4 ) of rats. The blot was hybridized with an EcoRI fragment of CBS cDNA obtained from Dr. J. P. Kraus. $B$, The membrane was stained with methylene blue before hybridization. Methylene blue stains RNA and allows the comparison of the amount of RNA loaded into each lane.

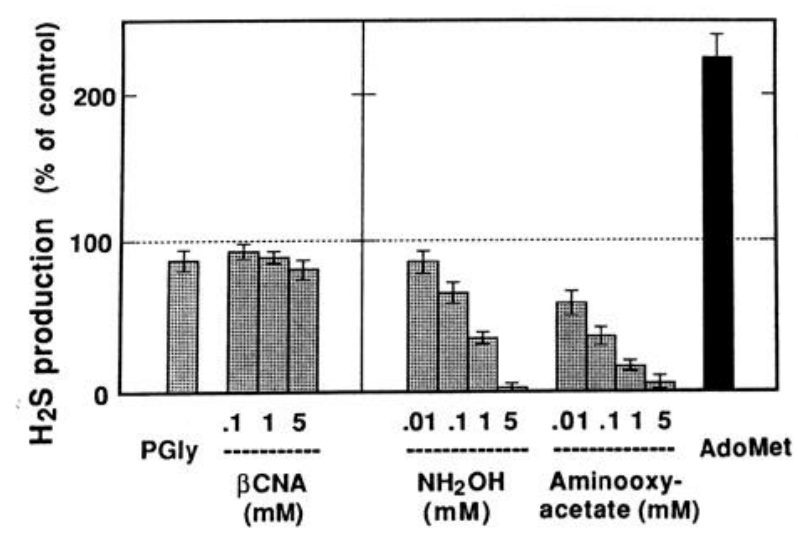

Figure 2. $\mathrm{H}_{2} \mathrm{~S}$ production in the brain. $\mathrm{H}_{2} \mathrm{~S}$ produced from cysteine in brain homogenates was measured. Brain homogenates produced $22.6 \pm$ $1.6 \mathrm{nmol} \mathrm{H}_{2} \mathrm{~S} / \mathrm{min}$ per G-protein $(n=7)$ in the presence of $10 \mathrm{~mm}$ L-cysteine and $2 \mathrm{~mm}$ pyridoxal 5 '-phosphate. CSE inhibitors D,Lpropargylglycine $(P G l y)$ and $\beta$-cyano-L-alanine $(\beta C N A)$ did not suppress the production of $\mathrm{H}_{2} \mathrm{~S}$. On the other hand, $\mathrm{CBS}$ inhibitors hydroxylamine $\left(\mathrm{NH}_{2} \mathrm{OH}\right)$ and amino-oxyacetate (Aminooxyacetate) suppressed $\mathrm{H}_{2} \mathrm{~S}$ production, and a CBS activator, $S$-adenosyl-L-methionine (AdoMet), potentiated the $\mathrm{H}_{2} \mathrm{~S}$ production. The values in drug-treated groups were expressed as a percentage of those in the control. All data are represented as the mean $\pm \mathrm{SEM}$ of five experiments.

$\mathrm{ml} / \mathrm{min})$. A stock solution of $\mathrm{NaHS}(100 \mathrm{~mm})$ was prepared by dissolving NaHS immediately before use.

\section{RESULTS}

\section{Expression of $\mathrm{H}_{2} \mathrm{~S}$-producing enzyme in the brain}

To determine whether CBS and CSE are present in rat brain, we tested the expression of their mRNAs by Northern blot analysis. CBS was highly expressed in the hippocampus and cerebellum compared with the cerebral cortex and brainstem (Fig. 1). Although a small amount of CSE mRNA was detected in the brain by PCR (Erickson et al., 1990), it was not detectable by Northern blot analysis (data not shown).

\section{$\mathrm{H}_{2} \mathrm{~S}$ production in the brain}

Because CBS is expressed in the brain, $\mathrm{H}_{2} \mathrm{~S}$ production in this tissue was measured according to the method by Stipanuk and Beck (1982). Brain homogenates produced $22.6 \pm 1.6 \mathrm{nmol} \mathrm{H}_{2} \mathrm{~S}$ / min per G-protein $(n=7)$ in the presence of $10 \mathrm{~mm} \mathrm{~L}$-cysteine and 2 mM pyridoxal $5^{\prime}$-phosphate. The $\mathrm{H}_{2} \mathrm{~S}$ production was suppressed by potent CBS inhibitors hydroxylamine $\left(\mathrm{IC}_{50}=10^{-4} \mathrm{M}\right)$ and amino-oxyacetate $\left(\mathrm{IC}_{50}=10^{-4} \mathrm{M}\right)$ (Braunstein et al., 1971) in a concentration-dependent manner (Fig. 2). Pretreatment with AdoMet, a specific activator of CBS $\left(\mathrm{EC}_{50}=10^{-4} \mathrm{M}\right)($ Finkelstein et al., 1975; Stipanuk and Beck, 1982), increased the $\mathrm{H}_{2} \mathrm{~S}$ production by $125 \%$ (Fig. 2). In contrast, D,L-propargylglycine, an irreversible inhibitor of CSE $\left(\mathrm{IC}_{50}=10^{-4} \mathrm{M}\right)$ that has no effect on CBS (Uren et al., 1978; Stipanuk and Beck, 1982), and $\beta$-cyanoL-alanine, a competitive inhibitor of $\operatorname{CSE}\left(\mathrm{IC}_{50}=10^{-5} \mathrm{M}\right)$, which also does not block CBS (Rfeffer and Ressler, 1967; Uren et al., 1978 ), only weakly suppressed the $\mathrm{H}_{2} \mathrm{~S}$ production (13 and $19 \%$, respectively).

\section{High concentrations of $\mathrm{H}_{2} \mathrm{~S}$ inhibit synaptic transmission in the hippocampus}

Because CBS is expressed and produces $\mathrm{H}_{2} \mathrm{~S}$ in the brain, and because the endogenous concentration of $\mathrm{H}_{2} \mathrm{~S}$ in the brain is relatively high $(50-160 \mu \mathrm{M})$ (Goodwin et al., 1989; Warenycia et al., 1989a; Savage and Gould, 1990), $\mathrm{H}_{2} \mathrm{~S}$ may play a role in 


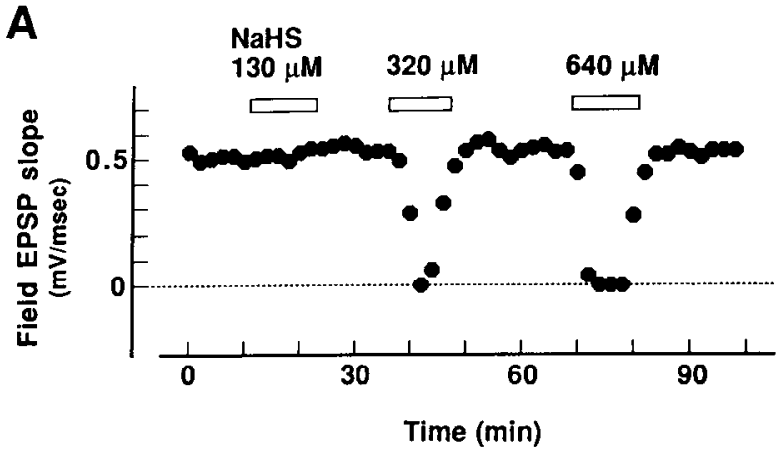

B Control $640 \mu \mathrm{M}$ NaHS Superimposed
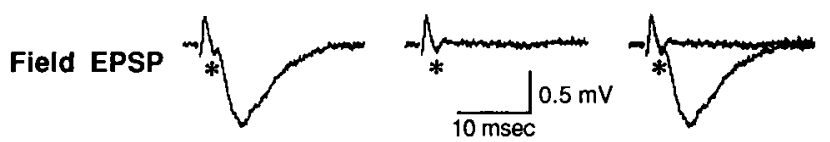

$\underset{\substack{\text { Population } \\ \text { spike }}}{\underset{n}{4}}$
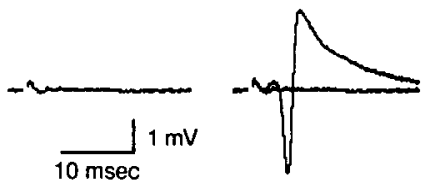

Figure 3. High concentrations of $\mathrm{H}_{2} \mathrm{~S}$ inhibit synaptic transmission in the hippocampus. $A$, NaHS ( 320 and $640 \mu \mathrm{M}$ ) decreased the slopes of the field EPSP in a concentration-dependent manner. NaHS was applied by perfusion during the times indicated by white bars. $B$, Sample records of field EPSPs and population spikes suppressed by $640 \mu \mathrm{M}$ NaHS. The signals denoted by asterisks represent the action potentials generated by direct stimulation of presynaptic fibers, which are completely abolished by $1 \mu \mathrm{M}$ tetrodotoxin, a $\mathrm{Na}^{+}$channel blocker.

synaptic transmission. The effect of $\mathrm{H}_{2} \mathrm{~S}$ on synaptic transmission was investigated by recording the field EPSPs and population spikes evoked by the electrical stimulation of the Schaffer collaterals in the CA 1 region of rat hippocampal slices. NaIIS was used as a source of $\mathrm{H}_{2} \mathrm{~S}$ for the following reasons. (1) NaHS dissociates to $\mathrm{Na}^{+}$and $\mathrm{HS}^{-}$in solution, then $\mathrm{HS}^{-}$ associates with $\mathrm{H}^{+}$and produces $\mathrm{H}_{2} \mathrm{~S}$. It does not matter whether the $\mathrm{H}_{2} \mathrm{~S}$ solution is prepared by bubbling $\mathrm{H}_{2} \mathrm{~S}$ gas or by dissolving NaHS. In physiological saline, approximately onethird of the $\mathrm{H}_{2} \mathrm{~S}$ exists as the undissociated form $\left(\mathrm{H}_{2} \mathrm{~S}\right)$, and the remaining two-thirds exists as $\mathrm{HS}^{-}$at equilibrium with $\mathrm{H}_{2} \mathrm{~S}$ (Beauchamp et al., 1984; Reiffenstein et al., 1992). (2) The use of NaHS enables us to define the concentrations of $\mathrm{H}_{2} \mathrm{~S}$ in solution more accurately and reproducibly than bubbling $\mathrm{H}_{2} \mathrm{~S}$ gas. (3) The influence of $\leq 1 \mathrm{~mm}$ sodium ion on the electrophysiological experiments is negligible, because the perfusing medium (ACSF) contains $150 \mathrm{~mm}$ sodium ion. (4) NaHS at concentrations used in the present study does not change the $\mathrm{pH}$ of butfered ACSF. For these reasons, NaHS has been widely used for studies of $\mathrm{H}_{2} \mathrm{~S}$ (Beauchamp et al., 1984; Warenycia ct al., 1989a,b; Kombian et al., 1993).

NaHS at concentrations of $\leq 130 \mu \mathrm{M}$ did not affect the field EPSPs (Fig. $3 A$ ) or the population spikes, whereas higher concentrations of NaHS ( 320 and $640 \mu \mathrm{M}$ ) suppressed both field EPSPs and the population spikes (Fig. $3 A, B$ ).

\section{Physiological concentrations of $\mathrm{H}_{2} \mathrm{~S}$ facilitate hippocampal LTP}

The abnormal expression of CBS activity causes several diseases, including mental retardation (Mudd et al., 1989). For example,
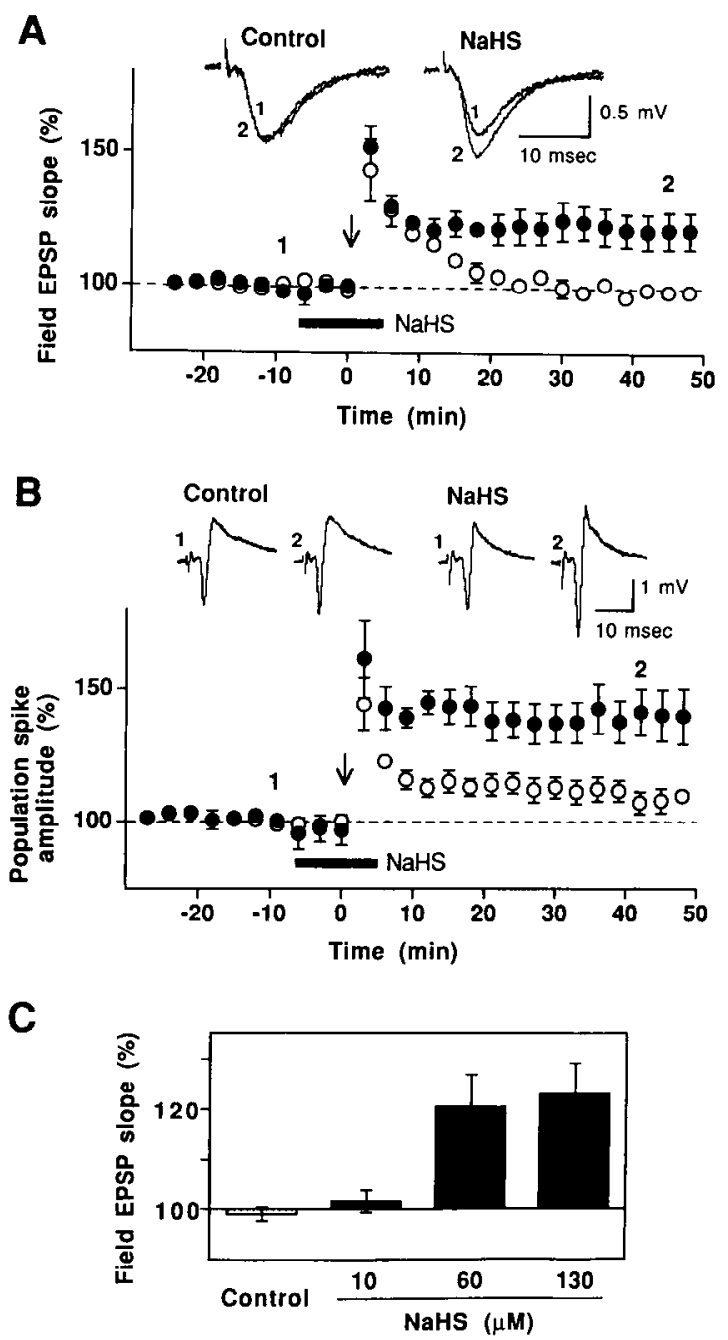

Figure 4. Physiological concentrations of $\mathrm{H}_{2} \mathrm{~S}$ facilitate the induction of hippocampal LTP. $A, B$, The effects of $130 \mu \mathrm{M}$ NaHS on a weak tetanic stimulation-induced potentiation of the field EPSPs $(A)$ and population spikes $(B)$. A weak tetanic stimulation (15 pulses at $100 \mathrm{~Hz}$; arrows), which alone did not induce I.TP (open circles), produced ITP in the presence of NaHS (filled circles). NaHS was applied by perfusion during the times indicated by black bars. The field EPSP slopes and the population spike amplitudes were expressed as the percentage of baseline values before the tetanic stimulation. The mean field EPSP slope $(123.1 \pm 6.6 \%, n=5)$ and the population spike amplitude $(139.5 \pm 8.5 \%, n=6) 30-48 \mathrm{~min}$ after the tetanic stimulation in the presence of NaHS were significantly different $(\rho$ $<0.05$, Student's $t$ test) from those in control (EPSP: $99.2 \pm 1.2 \%, n=6$; spike: $110.3 \pm 4.0 \%, n=5$ ). Representative records at the times denoted by the numbers are shown as insets. C; Concentration dependency of the LTP-facilitating effect of NaHS. The mean field EPSP slope 30-48 min after the weak tetanic stimulation was measured. All data are represented as the mean \pm SEM.

the CBS gene is located on the chromosome 21, and trisomy 21 in Down syndrome may contribute to the pathophysiology of this disease (Kraus, 1990). We therefore examined the effect of physiological concentrations of $\mathrm{H}_{2} \mathrm{~S}$ on LTP. To test whether $\mathrm{H}_{2} \mathrm{~S}$ has an effect on the induction of LTP, we first assayed the effect of $\mathrm{NaHS}$ at concentrations $\leq 130 \mu \mathrm{M}$ with a weak tetanic stimulation (15 pulses at $100 \mathrm{~Hz}$ ), which alone did not induce LTP. In the presence of $130 \mu \mathrm{M} \mathrm{NaHS}$, a weak tetanic stimulation induced LTPs of both the field EPSPs and the population spikes (Fig. $4 A, B)$. This effect of $\mathrm{H}_{2} \mathrm{~S}$ was concentration-dependent in the range of $10-130 \mu \mathrm{M}$ (Fig. $4 C$ ). To test whether $\mathrm{H}_{2} \mathrm{~S}$ is required at 

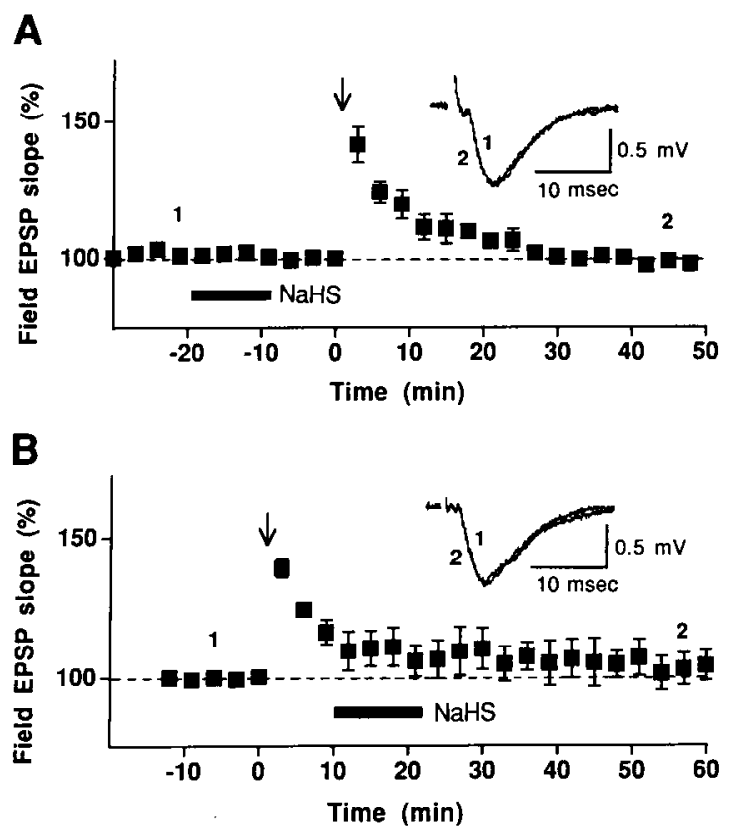

Figure 5. Simultaneous application of $\mathrm{H}_{2} \mathrm{~S}$ with a tetanic stimulation is required for the induction of LTP. $A, B$, When $130 \mu \mathrm{M}$ NaHS was applied $10 \mathrm{~min}$ before $(A)$ or $10 \mathrm{~min}$ after $(B)$ the application of a weak tetanic stimulation (15 pulses at $100 \mathrm{~Hz}$ ), LTP was not induced $(n=5)$.

the same time as the tetanic stimulation, we added NaHS $10 \mathrm{~min}$ before or after the tetanic stimulation. The perfusion of $130 \mu \mathrm{M}$ $\mathrm{NaHS}$ either before or after a weak tetanic stimulation did not facilitate the induction of LTP (Fig. 5). These results indicate that the physiological concentrations of $\mathrm{H}_{2} \mathrm{~S}$ facilitate the induction of LTP only when it is simultaneously applied with a weak tetanic stimulation.

If the potentiation induced by a weak tetanic stimulation in the presence of $\mathrm{H}_{2} \mathrm{~S}$ shares common mechanisms with LTP induced by a strong tetanic stimulation, they should occlude each other. To test this possibility, occlusion experiments (Zhuo et al., 1993; Kang and Schuman, 1995) were performed. It was tested whether $\mathrm{H}_{2} \mathrm{~S}$-induced potentiation occludes the induction of LTP by a strong tetanic stimulation. After potentiation induced by $\mathrm{H}_{2} \mathrm{~S}$ with a weak tetanic stimulation reached a plateau, a strong tetanic stimulation (100 pulses at $100 \mathrm{~Hz}$, twice at an interval of $20 \mathrm{sec}$ ) was applied. There was no significant difference between LTP induced by a strong tetanic stimulation after the application of $\mathrm{H}_{2} \mathrm{~S}$ and that of control (Fig. $6 A$ ). It was also tested whether the induction of LTP by a strong tetanic stimulation occludes $\mathrm{H}_{2} \mathrm{~S}$ induced potentiation. After LTP had been induced by a strong tetanic stimulation, $\mathrm{H}_{2} \mathrm{~S}$ with a weak tetanic stimulation produced no further potentiation (Fig. $6 B$ ). These results indicate that the $\mathrm{H}_{2} \mathrm{~S}$-induced LTP shares common mechanisms with LTP induced by a strong tetanic stimulation.

The observation that $\mathrm{NO}$ and $\mathrm{CO}$ induce LTP even under the blockade of NMDA receptors (Zhuo et al., 1993) supports the idea that $\mathrm{NO}$ and $\mathrm{CO}$ act as retrograde messengers at synapses (O'Dell et al., 1991; Schuman and Madison, 1991; Stevens and Wang, 1993). To determine whether the facilitation of LTP by $\mathrm{H}_{2} \mathrm{~S}$ requires NMDA receptor activation, the effect of NaHS on LTP induction in the presence of 2-amino-5-phosphonovalerate (APV), an NMDA receptor antagonist, was examined. NaHS (130 $\mu \mathrm{M})$ with a weak tetanic stimulation did not induce LTP in the presence of $50 \mu \mathrm{M}$ APV (mean field EPSP slope 30 min after
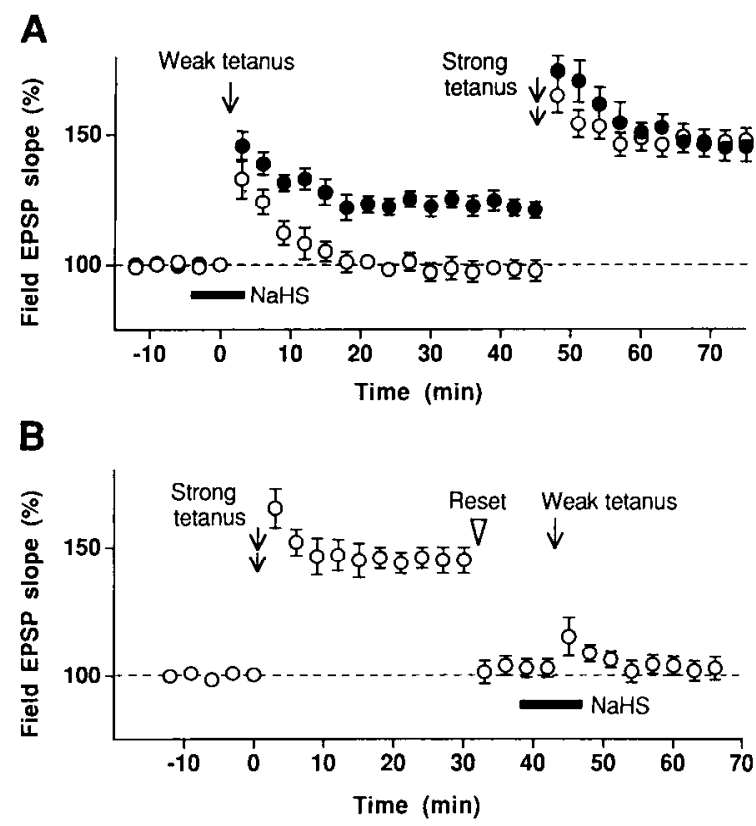

Figure 6. Potentiation induced by $\mathrm{H}_{2} \mathrm{~S}$ is not additive with LTP induced by a strong tetanic stimulation. $A$, In control slices (open circles), a weak tetanic stimulation (single arrow) was first applied in the absence of NaHS and then LTP was induced by a strong tetanic stimulation ( 100 pulses at $100 \mathrm{~Hz}$, twice at an interval of $20 \mathrm{sec}$; double arrow). In tested slices (filled circles), after LTP had been induced by $130 \mu \mathrm{M}$ NaHS (black bar) paired with a weak tetanic stimulation (single arrow), a strong tetanic stimulation was applied (double arrow). Strong tetanic stimulation-induced LTP in the slices previously potentiated by $\mathrm{H}_{2} \mathrm{~S}$ (mean EPSP slope, $149.4 \pm 5.5 \%, n$ $=5$ ) was not significantly different from that in control slices (147.3 \pm $4.2 \%, n=5$ ). $B$, After LTP had been induced by a strong tetanic stimulation (double arrow), the potentiated response was reset by reducing stimulus intensity (open arrowhead), and the effect of $130 \mu \mathrm{M} \mathrm{NaHS}$ with a weak tetanic stimulation (single arrow and bar) was examined. LTP induced by a strong tetanic stimulation completely occluded $\mathrm{H}_{2} \mathrm{~S}$-induced potentiation.

tetanus, $99.6 \pm 0.4 \%, n=4$ ), suggesting that the induction of LTP by $\mathrm{H}_{2} \mathrm{~S}$ requires the activation of NMDA receptors.

\section{$\mathrm{H}_{2} \mathrm{~S}$ enhances NMDA receptor-mediated responses}

Hippocampal LTP induced by a tetanic stimulation requires the activation of NMDA receptors (Collingridge et al., 1983; Harris et al., 1984). To determine whether $\mathrm{H}_{2} \mathrm{~S}$ modifies NMDA receptors, we examined the effect of physiological concentrations of $\mathrm{H}_{2} \mathrm{~S}$ on NMDA-induced currents by whole-cell patch recording with hippocampal slices. Bath application of NMDA $(20 \mu \mathrm{M}, 90 \mathrm{sec})$ induced an inward current of $524.7 \pm 51.4 \mathrm{pA}(n=7)$ at a holding potential of $-60 \mathrm{mV}$ (Fig. $7 A 1, C$ ). NaHS $(130 \mu \mathrm{M})$ alone did not induce any apparent currents but significantly increased the NMDA-induced inward current (Fig. 7A2,C). This effect of NaHS disappeared after it was washed out (Fig. $7 A 3, C$ ). The NMDAinduced current was completely blocked by APV, confirming that the response was mediated by NMDA receptors (Fig. 7A4). The enhancing effect of $\mathrm{H}_{2} \mathrm{~S}$ on NMDA response was concentrationdependent in the range of $10-130 \mu \mathrm{M}$ (Fig. 7D), consistent with its LTP-facilitating effect (Fig. $4 C$ ). Although the effect of $\mathrm{II}_{2} \mathrm{~S}$ was already saturated at $130 \mu \mathrm{M}$, up to $200 \mu \mathrm{M} \mathrm{H}_{2} \mathrm{~S}$ potentiated NMDA responses. We could not perform patch-clamp analysis at higher concentrations of $\mathrm{H}_{2} \mathrm{~S}$ because the membrane potential was unstable, which was probably attributable to the general toxicity of high concentrations of $\mathrm{H}_{2} \mathrm{~S}$. In contrast, even $130 \mu \mathrm{M}$ NaHS had no effect on the currents induced by a non-NMDA 

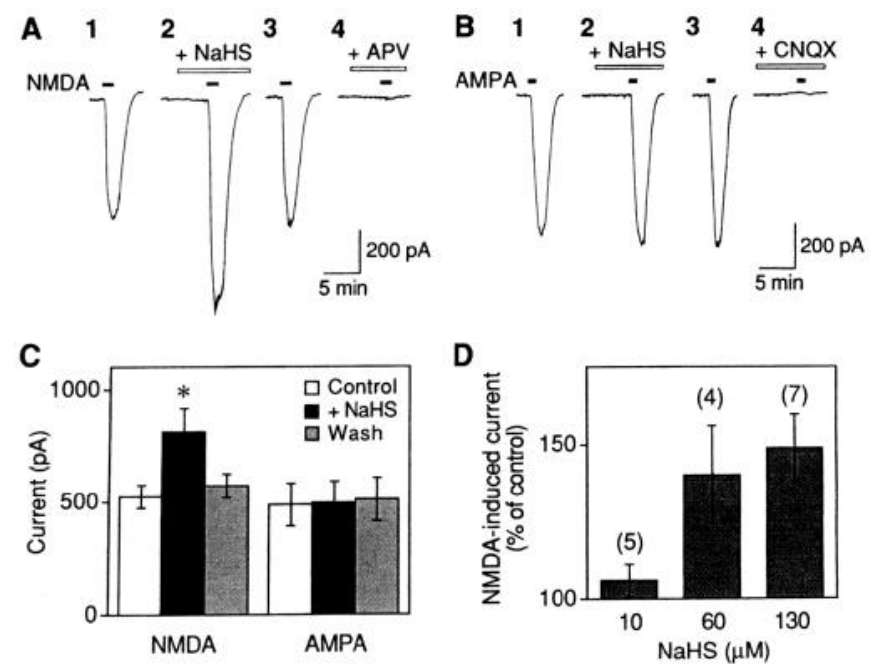

Figure 7. $\mathrm{H}_{2} \mathrm{~S}$ selectively enhances NMDA receptor-mediated currents. $A, B$, Representative records of inward currents induced by bath application of $N M D A(20 \mu \mathrm{M}, 90 \mathrm{sec} ; A)$ or $A M P A(10 \mu \mathrm{M}, 60 \mathrm{sec} ; B)$ at a holding potential of $-60 \mathrm{mV}$. 1 , control; 2 , in the presence of $130 \mu \mathrm{M} \mathrm{NaHS} ; 3,20$ min after washing out NaHS; 4 , in the presence of $50 \mu \mathrm{M}$ APV $(A)$ or 30 $\mu \mathrm{M}$ CNQX $(B) . C$, Collected data of the effects of $130 \mu \mathrm{M}$ NaHS on inward currents induced by NMDA $(n=7)$ or AMPA $(n=5)$. The responses to each agonist were evaluated by measuring peak current amplitude. $\left({ }^{*} p<\right.$ 0.05 vs control; paired $t$ test). $D$, Concentration dependency of the enhancement of NMDA response by NaHS. NMDA-induced currents in the presence of NaHS were normalized by taking each control value as $100 \%$. The numbers of observations are shown in parentheses.

receptor agonist AMPA $(10 \mu \mathrm{M}, 60 \mathrm{sec})$ (Fig. $7 B 1-3, C)$. The AMPA-induced current was completely blocked by 6-cyano-7nitroquinoxaline-2,3-dione (CNQX), a non-NMDA receptor antagonist (Fig. 7B4). The failure of $\mathrm{H}_{2} \mathrm{~S}$ to enhance AMPA response was not attributable to saturation of the AMPA response because application of a higher concentration $(30 \mu \mathrm{M})$ of AMPA induced larger currents (963.6 $\pm 53.5 \mathrm{pA}, n=5)$. These results indicate that physiological concentrations of $\mathrm{H}_{2} \mathrm{~S}$ selectively enhance the function of NMDA receptors.

Disulfide bonds play a role in modulating the function of many proteins, including NMDA receptors (Aizenman et al., 1989; Tang and Aizenman, 1993). It is therefore possible that $\mathrm{H}_{2} \mathrm{~S}$ interacts with disulfide bonds or free thiols in NMDA receptors. To test this possibility, we determined the effect of the irreversible thiol-protecting agent dithiothreitol (DTT) on the LTPfacilitating action of NaHS. DTT $(1 \mathrm{~mm})$ with a weak tetanic stimulation, which by itself does not cause LTP weakly, but significantly, facilitated the induction of LTP (Fig. 8). NaHS with a weak tetanic stimulation, however, still induced LTP even after treatment with DTT (Fig. 8), demonstrating that DTT does not occlude the effect of $\mathrm{H}_{2} \mathrm{~S}$. These observations suggest that the thiol redox sites contribute little, if any, to the potentiating effect of $\mathrm{H}_{2} \mathrm{~S}$ on the induction of LTP.

\section{DISCUSSION}

Endogenous $\mathrm{H}_{2} \mathrm{~S}$ is formed primarily by CBS and CSE (Stipanuk and Beck, 1982; Griffith, 1987; Erickson et al., 1990; Swaroop et al., 1992). CBS is expressed in the brain (Fig. 1). The production of $\mathrm{H}_{2} \mathrm{~S}$ in the brain is suppressed efficiently by CBS inhibitors hydroxylamine and amino-oxyacetate and is strongly potentiated by a CBS activator, AdoMet (Fig. 2). In contrast, the expression in the brain of another $\mathrm{H}_{2} \mathrm{~S}$-producing enzyme, CSE, is under de- tectable levels by Northern blot analysis. CSE inhibitors D,Lpropargylglycine and $\beta$-cyano-L-alanine do not suppress the production of $\mathrm{H}_{2} \mathrm{~S}$ in the brain (Fig. 2), although these inhibitors suppress $\mathrm{H}_{2} \mathrm{~S}$ production effectively in the liver and kidney (Stipanuk and Beck, 1982). It is unlikely that the other pyridoxal5 '-phosphate-dependent enzyme, cysteine aminotransferase, contributes to the production of endogenous $\mathrm{H}_{2} \mathrm{~S}$, because it requires a pH much above physiological levels (Ubuka et al., 1978; Stipanuk and Beck, 1982). These observations indicate that CBS must be the major enzyme that produces endogenous brain $\mathrm{H}_{2} \mathrm{~S}$.

Physiological concentrations of $\mathrm{H}_{2} \mathrm{~S}$ induce LTP only when it is applied associatively with a weak tetanic stimulation, which alone does not induce LTP (Figs. 4, 5). In addition, occlusion experiments (Fig. 6) show that the potentiation induced by $\mathrm{H}_{2} \mathrm{~S}$ with a weak tetanic stimulation shares common mechanisms with LTP induced by a strong tetanic stimulation. Therefore, $\mathrm{H}_{2} \mathrm{~S}$ facilitates LTP at active, but not quiescent, synapses, suggesting that $\mathrm{H}_{2} \mathrm{~S}$ is involved in associative learning as defined by Hebb (1949).

Although $\mathrm{H}_{2} \mathrm{~S}$, like $\mathrm{NO}$ and $\mathrm{CO}$, facilitates the induction of LTP, the mechanism of action of $\mathrm{H}_{2} \mathrm{~S}$ is different from those of $\mathrm{NO}$ and $\mathrm{CO}$. First, long-term enhancement by $\mathrm{NO}$ or CO does not require NMDA receptor activation (Zhuo et al., 1993), whereas the LTP-facilitating effect of $\mathrm{H}_{2} \mathrm{~S}$ is not observed under the blockade of NMDA receptors, suggesting that $\mathrm{H}_{2} \mathrm{~S}$ may not act as a retrograde messenger. Second, NO and CO increase the intracellular cyclic GMP (Garthwaite, 1991; Bredt and Snyder, 1992; Verma et al., 1993), whereas $\mathrm{H}_{2} \mathrm{~S}$ does not (our unpublished data). Finally, we found that physiological concentrations of $\mathrm{H}_{2} \mathrm{~S}$ selectively increase NMDA receptor-mediated responses (Fig. 7).

High concentrations of $\mathrm{H}_{2} \mathrm{~S}(>320 \mu \mathrm{M})$ inhibit synaptic transmission in the hippocampus (Fig. 3). Although in the presence of taurine, NaHS inhibits the tetrodotoxin-sensitive sodium channels (Warenycia et al., 1989b), the suppression of EPSPs and population spikes by high concentrations of $\mathrm{NaHS}$ in the present study is unlikely to be attributable to the inhibition of sodium channels because NaHS does not inhibit the presynaptic fiber volleys (Fig. $3 B$, asterisks). The lethal concentration of $\mathrm{H}_{2} \mathrm{~S}$ in the brain is only twice as much of an endogenous concentration of $\mathrm{H}_{2} \mathrm{~S}$ in the rat (Warenycia et al., 1989a). The suppressive effect of $\mathrm{H}_{2} \mathrm{~S}$ on synaptic transmission in the CNS may be partly responsible for the dizziness and unconsciousness caused by acute sublethal $\mathrm{H}_{2} \mathrm{~S}$ exposure (Reiffenstein et al., 1992).

An additional experiment to support the role of endogenous $\mathrm{H}_{2} \mathrm{~S}$ in the induction of LTP is to test whether the induction of

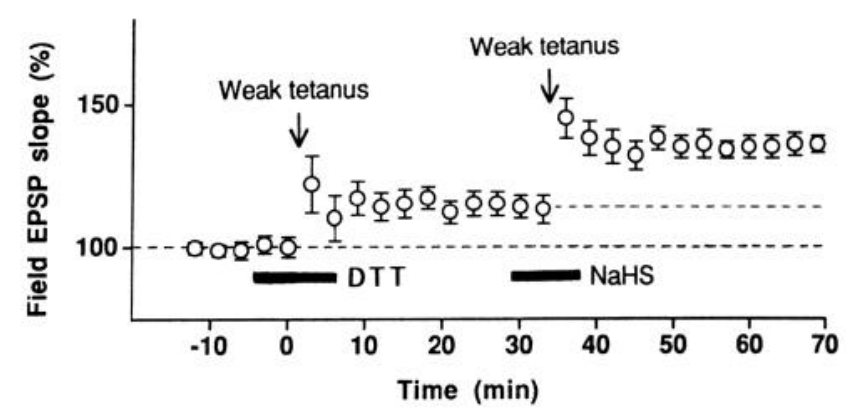

Figure 8. Pretreatment with DTT does not occlude the LTP-facilitating effect of $\mathrm{H}_{2} \mathrm{~S}$. DTT ( $1 \mathrm{~mm}$ ) was applied during the time indicated by solid bars. After treatment with DTT, a weak tetanic stimulation $(15$ pulses at $100 \mathrm{~Hz}$ ) induced a small LTP. NaHS $(130 \mu \mathrm{M})$ with a weak tetanic stimulation (15 pulses at $100 \mathrm{~Hz}$ ) induced an additional LTP even after treatment with DTT. A weak tetanic stimulation by itself does not cause LTP. 
LTP is blocked by the inhibitors of ${ }^{\prime} \mathrm{H}_{2} \mathrm{~S}$ production. Although hydroxylamine and amino-oxyacetate suppress the production of $\mathrm{H}_{2} \mathrm{~S}$ (Fig. 2), they could not be used to test the role of endogenous $\mathrm{H}_{2} \mathrm{~S}$ in LTP for the following reasons. Amino-oxyacetate (0.5-1 $\mathrm{mM})$ suppresses the baseline field EPSP by $23.3 \pm 4.7 \%(n=4)$. In addition to the inhibitory effect on CBS, hydroxylamine produces NO (Southam and Garthwaite, 1991). AdoMet, a specific activator for CBS, did not significantly potentiate the induction of LTP because it is unable to enter the cell. In addition, AdoMet must be added to brain homogenates at least $15 \mathrm{~min}$ before the reaction with CBS, suggesting that it only activates CBS with time. The development of more specific and potent inhibitors for $\mathrm{H}_{2} \mathrm{~S}$ producing enzymes is required.

In addition to changes in enzyme activity, there are at least two substances that change the concentration of $\mathrm{H}_{2} \mathrm{~S}$; they are cysteine and AdoMet. Cysteine is a source of $\mathrm{H}_{2} \mathrm{~S}$. Its concentration may be changed when the glutamate/cystine transporter (Murphy et al., 1989) is locally inhibited by the increased extracellular glutamate, an excitatory neurotransmitter. AdoMet activates CBS resulting in the increase in $\mathrm{H}_{2} \mathrm{~S}$ production (Fig. 2), and the concentration of AdoMet is changed by testosterone (ManteuffelCymborowska et al., 1992). Therefore, it is possible that $\mathrm{H}_{2} \mathrm{~S}$ is involved in the modulation of synaptic activities regulated by steroid hormones and neurotransmitters.

It can be concluded that $\mathrm{H}_{2} \mathrm{~S}$ is produced in the brain largely by the activity of CBS and that $\mathrm{H}_{2} \mathrm{~S}$ may be involved in associative learning.

\section{REFERENCES}

Aizenman E, Lipton DA, Loring RH (1989) Selective modulation of NMDA responses by reduction and oxidation. Neuron 2:1257-1263.

Beauchamp RO, Bus JS, Popp JA, Boreiko CJ, Andjelkovich DA (1984) A critical review of the literature on hydrogen sulfide. Crit Rev Toxicol 13:25-97.

Bliss TVP, Collingridge GL (1993) A synaptic model of memory: longterm potentiation in the hippocampus. Nature 361:31-39.

Braunstein AE, Goryachenkova EV, Tolosa EA, Willhardt IH, Yefremova LL (1971) Specificity and some other properties of liver serine sulphhydrase: evidence for its identity with cystathionine $\beta$-synthase. Biochim Biophys Acta 242:247-260.

Bredt DS, Snyder SH (1992) Nitric oxide, a novel neuronal messenger. Neuron 8:3-11.

Collingridge GL, Kehl SJ, McLennan H (1983) Excitatory amino acids in synaptic transmission in the Schaffer collateral -commissural pathway of the rat hippocampus. J Physiol 334:33-46.

Frickson PF, Maxwell IH, Su LJ, Baumann M, Glode LM (1990) Sequence of cDNA for rat cystathionine $\gamma$-lyase and comparison of deduced amino acid sequence with related Escherichia coli enzymes. Biochem J 269:335-340.

Finkelstein JD, Kyle WE, Martin JJ, Pick AM (1975) Activation of cystathionine synthase by adenosylmethionine and adenosylethionine. Biochem Biophys Res Commun 66:81-87.

Garthwaite J (1991) Glutamate, nitric oxide and cell-cell signalling in the nervous system. Trends Neurosci 14:60-67.

Goodwin LR, Francom D, Dieken FP, Taylor JD, Warenycia MW, Reiffenstein RJ, Dowling G (1989) Determination of sulfide in brain tissue by gas dialysis/ion chromatography: postmortem studies and two case reports. J Anal Toxicol 13:105-109.

Griffith OW (1987) Mammalian sulfur amino acid metabolism: an overview. In: Methods in enzymology 143, pp 366-376. New York: Academic.

Haley JE, Wilcox GL, Chapman PF (1992) The role of nitric oxide in hippocampal long-term potentiation. Neuron 8:211-216.

Harris EW, Ganong AH, Cotman CW (1984) Long-term potentiation in the hippocampus involves activation of $N$-methyl-D-aspartate receptors. Brain Res 323:132-137.
Hcbb DO (1949) The organization of bchavior. Ncw York: Wilcy.

Kang H, Schuman EM (1995) Long-lasting neutrophin-induced enhancement of synaptic transmission in the adult hippocampus. Science 267:1658-1662.

Kombian SB, Reiffenstein RJ, Colmers WF (1993) The actions of hydrogen sulfide on dorsal raphe serotonergic neurons in vitro. J Neurophysiol 70:81-96.

Kraus JP (1990) Molecular analysis of cystathionine $\beta$-synthase - a gene on chromosome 21. In: Molecular genetics of chromosome 21 and Down syndrome, pp 201-214. New York: Wiley.

Maines MD (1988) Heme oxygenase: function, multiplicity, regulatory mechanisms, and clinical applications. FASEB J 2:2557-2568.

Manteuffel-Cymborowska M, Chmurzynska W, Grzelakowska-Sztabert B (1992) Tissue-specific effects of testosterone on $S$-adenosylmethionine formation and utilization in the mouse. Biochim Biophys Acta 1116:166-172.

Mudd SH, Levy HL, Skovby F (1989) Disorders of transsulfuration. In: The metabolic basis of inherited disease (Scriver CR, Beaudet AL, Sly WS, Valle D, eds), pp 693-734. New York: McGraw-Hill.

Murphy TH, Miyamoto M, Sastre A, Schnaar RL, Coyle JT (1989) Glutamate toxicity in a neuronal cell line involves inhibition of cystine transport leading to oxidative stress. Neuron 2:1547-1558.

O'Dell TJ, Hawkins RD, Kandel ER, Arancio O (1991) Tests of the roles of two diffusible substances in long-term potentiation: evidence for nitric oxide as a possible early retrograde messenger. Proc Natl Acad Sci USA 88:11285-11289.

Palmer RMJ, Ashton DS, Moncada S (1988) Vascular endothelial cells synthesize nitric oxide from L-arginine. Nature 333:664-666.

Reiffenstein RJ, IIulbert WC, Roth SH (1992) Toxicology of hydrogen sulfide. Annu Rev Pharmacol Toxicol 32:109-134.

Rfeffer M, Ressler C (1967) $\beta$-Cyanoalanine, an inhibitor of rat liver cystathionase. Biochem Pharmacol 16:2299-2308.

Savage JC, Gould DH (1990) Determination of sulfides in brain tissue and rumen fluid by ion-interaction reversed-phase high-performance liquid chromatography. J Chromatogr 526:540-545.

Schuman EM, Madison DV (1991) A requirement for the intercellular messenger nitric oxide in long-term potentiation. Science 254:1503-1506.

Southam E, Garthwaite J (1991) Comparative effects of some nitric oxide donors on cyclic GMP levels in rat cerebellar slices. Neurosci Lett 130:107-111.

Stevens CF, Wang Y (1993) Reversal of long-term potentiation by inhibitors of haem oxygenase. Nature 364:147-149.

Stipanuk MII, Beck PW (1982) Characterization of the enzymic capacity for cysteine desulphhydration in liver and kidney of the rat. Biochem J 206:267-277.

Swaroop M, Bradley K, Ohura T, Tahara T, Roper MD, Rosenberg LE, Kraus JP (1992) Rat cystathionine $\beta$-synthase. J Biol Chem 267: 11455-11461.

Tang L-H, Aizenman E (1993) The modulation of $N$-methyl-D-aspartate receptors by redox and alkylating reagents in rat cortical neurones in vitro. J Physiol (Lond) 465:303-323.

Ubuka T, Umemura S, Yuasa S, Kinuta M, Watanabe K (1978) Purification and characterization of mitochondrial cysteine aminotransferase from rat liver. Physiol Chem Phys Med NMR 10:483-500.

Uren JR, Ragin R, Chaykovsky M (1978) Modulation of cysteine metabolism in mice - effects of propargylglycine and L-cyst(e)ine-degrading enzymes. Biochem Pharmacol 27:2807-2814.

Verma A, Hirsch DJ, Glatt CE, Ronnett GV, Snyder SH (1993) Carbon monoxide: a putative neural messenger. Science 259:381-384.

Warenycia MW, Goodwin LR, Benishin CG, Reiffenstein RJ, Francom DM, Taylor JD, Dieken FP (1989a) Acute hydrogen sulfide poisoning: demonstration of selective uptake of sulfide by the brainstem by measurement of brain sulfide levels. Biochem Pharmacol 38:973-981.

Warenycia MW, Steele JA, Karpinski E, Reiffenstein RJ (1989b) Hydrogen sulfide in combination with taurine or cysteic acid reversibly abolishes sodium currents in neuroblastoma cells. Neurotoxicology 10:191-200.

Zhuo M, Small SA, Kandel ER, Hawkins RD (1993) Nitric oxide and carbon monoxide produce activity-dependent long-term synaptic enhancement in hippocampus. Science 260:1946-1950. 